\title{
EMANCIPACIÓN Y GUERRA \\ EN EL RÍO DE LA PLATA, 1840-1865: \\ HACIA UNA HISTORIA SOCIAL DE LAS \\ RELACIONES INTERNACIONALES
}

\author{
Keila Grinberg \\ Universidade Federal do Estado do Rio de Janeiro (UNIRIO)
}

Desde la guerra contra el dictador argentino Rosas [...] el Estado Oriental del Uruguay se convirtió en el más delicado y peligroso problema de nuestra política exterior.

Joaquim Nabuco, político brasileño, en Um Estadista do Império

\begin{abstract}
A penas amanecía el día 4 de agosto de 1864 y José Antonio 1 Saraiva, enviado especial de Brasil en Montevideo, ya había entregado su ultimátum al gobierno uruguayo; el presidente Aguirre tendría seis días para atender los pedidos de indemnización de los brasileños residentes en aquel país, que querían ser resarcidos por los daños que venían siendo causados a sus propiedades desde hacía más de diez años. En caso contrario, tropas brasileñas atacarían Uruguay. La respuesta uruguaya no tardó: el documento fue devuelto al representante brasileño
\end{abstract}

Fecha de recepción: 3 de mayo de 2018

Fecha de aceptación: 4 de julio de 2018 
"por inaceptable" que era, indigno incluso de "permanecer en los archivos orientales". ${ }^{1}$

Menos de tres meses después, Brasil invadiría el norte de Uruguay. La acción brasileña sería fundamental para la deposición de Aguirre, representante de los "blancos" en el poder. En su lugar, asumió la presidencia el “colorado" Venancio Flores, dando fin a la guerra civil que hacía más de un año dividía al país. Es posible que entonces nadie tuviera todavía conciencia de que, en aquel momento, dio inicio el mayor conflicto armado de la historia de América del Sur. La Guerra del Paraguay, Guerra Grande o Guerra de la Triple Alianza se prolongó por casi seis años y provocó centenas de miles de muertos entre civiles y combatientes. $^{2}$

Desde su eclosión, la guerra del Paraguay fue objeto de intensa controversia por parte de políticos, historiadores y estudiosos en general. Los primeros libros al respecto, muchos con copias de importantes documentos diplomáticos, fueron publicados en la década de 1870. En 1894, el liberal José Antonio Saraiva -que, después del fracaso de su misión en el Plata, tendría larga carrera política en el Imperio de Brasil-se defendió públicamente de las acusaciones del uruguayo Sagastume, de que él había sido incapaz de llevar a buen término las negociaciones diplomáticas con los uruguayos y responsable del comienzo de la guerra. A su defensa llegó el también político liberal brasileño Joaquim Nabuco, que en su obra prima $U m$

\footnotetext{
1 Acuerdo de 4 de agosto de 1861, Ministerio de Relaciones Exteriores, Montevideo, Documentos Diplomáticos, Misión Saraiva, p. 60, nota 1.

2 De aquí en adelante el conflicto será referido como Guerra del Paraguay. En diciembre de 1864, Paraguay, con quien los blancos uruguayos habían hecho una alianza, reclamaron lo que consideraron una declaración de guerra brasileña e invadieron la provincia brasileña de Mato Grosso y la provincia argentina de Corrientes con el objetivo de llegar a Montevideo. Brasil y Argentina, aliados de los colorados de tiempo atrás, se unieron en el intento de detener a los paraguayos. Para el contexto histórico de la guerra véase Doratioto, Maldita Guerra.
} 
Estadista do Império afirmó que gracias a Saraiva Brasil había conseguido cerrar los acuerdos con Argentina y los colorados en Uruguay, formando la triple alianza y desempeñando en la guerra "el papel de representante desinteresado de la civilización y de la libertad en América del Sur". ${ }^{3}$

No deja de ser curiosa la afirmación de Nabuco, uno de los abolicionistas brasileños más conocidos: al momento del inicio de la guerra, aunque la esclavitud todavía existía residualmente en Paraguay (fue abolida en 1869), Brasil era el único país esclavista de la región. A lo largo del siglo xx y comienzos del xxi, las diversas interpretaciones sobre las causas y las motivaciones de los países involucrados en la guerra -Brasil, Uruguay, Argentina, Paraguay, y para algunos Inglaterra-, aunque no mencionen la esclavitud, están lejos de refrendar el supuesto interés brasileño en el fomento de la civilización y la libertad.

No es el objetivo de este artículo discutir en detalle la historia de la historiografía de la Guerra del Paraguay. Desde la década de 1990 algunos historiadores argumentan que la guerra debe ser comprendida dentro del "proceso de construcción y consolidación de los Estados-Nación en el Río de la Plata”, y es desde este principio que este texto parte. Límites mal definidos, derechos de navegación por los ríos de la región, producción de yerba mate en las fronteras, acceso de los paraguayos al estuario del Plata y contrabando de ganado en la frontera entre Brasil y Uruguay son considerados como algunas de las principales razones del inicio del conflicto, que revelan antiguos intereses expansionistas y disputas por la hegemonía política local. ${ }^{4}$

Las razones de la ocupación brasileña del norte de Uruguay en octubre de 1864, por su parte, curiosamente carecen de un

\footnotetext{
${ }^{3}$ Resposta do conselheiro José Antonio Saraiva ao dr. Vasquez Sagastume; Nabuco, Um Estadista, pp. 507-508.

${ }^{4}$ Doratioto, Maldita Guerra, p. 18. La historiografía sobre la Guerra del Paraguay es un tema aparte. Al respecto, véase, además de Doratioto, SAlles, Guerra do Paraguai, e Izecksonn, Slavery and War in the Americas.
} 
análisis más minucioso. Las interpretaciones actuales atribuyen el fracaso de la misión Saraiva -fracaso por no haber evitado el conflicto- a la imposibilidad de atender las reclamaciones de ambas partes, que genéricamente se refieren a ataques a propiedades y a la seguridad de los brasileños que vivían en Uruguay, y a la falta de respeto brasileña por la soberanía y la legislación uruguayas, causando continuos desórdenes en la región. Pero, al final, ¿qué reclamaban brasileños y uruguayos? Y ¿por qué estas reclamaciones eran tan importantes para llevar a los brasileños a invadir territorio uruguayo?

Siguiendo una línea diferente de las interpretaciones actuales sobre el tema, pretendo argumentar que, para entender plenamente las causas de las quejas mutuas entre los dos países -y, por lo tanto, el inicio de la guerra- es preciso considerar las tensiones en torno a la abolición de la esclavitud en Uruguay y a la prohibición final del tráfico de esclavos en Brasil, ocurridas, respectivamente, en las décadas de 1840 y 1850 . Estas tensiones son parte de las disputas relativas a la consolidación de los Estados nacionales locales y centrales para comprender el proceso histórico que desencadenó la guerra del Paraguay. ${ }^{5}$

La abolición de la esclavitud en Uruguay fue proclamada en 1842 y 1846 por, respectivamente, colorados y blancos, en el contexto de la guerra civil que asoló el país entre 1839 y 1851. Estas leyes establecieron que tierras uruguayas serían consideradas libres; que, al contrario del imperio esclavista brasileño, la nación se definiría como "suelo libre" (free soil). ${ }^{6}$ En este periodo, los límites que antes habían sido objeto de disputa entre los imperios coloniales español y portugués pasaron a tener

5 Excepciones son las interpretaciones de SAlles, Guerra do Paraguai, y Mario Maestri, “A intervenção do Brasil no Uruguai e a Guerra do Paraguai: a missão Saraiva”. Comunicação apresentada ao V Encuentro de Historia sobre las operaciones belicas durante la Guerra de la Triple Alianza, Montevideo, Uruguay, 23-25 de octubre de 2013.

6 Para el concepto de suelo libre véase Peabody y Grinberg, Free Soil. 
un nuevo significado, por lo menos en la ley (y la ley importa mucho): quien cruzase la frontera de Brasil con Uruguay no sería más esclavo, y nadie podría ser reesclavizado si volviese a pisar suelo brasileño, gracias a la ley de prohibición del tráfico de 1831.

Espero dejar claro que estas razones fueron suficientes para exacerbar las tensiones entre brasileños y uruguayos en la frontera desde el fin de la década de 1840. En el inicio de la década de 1860, éstas llegarían a un punto irreversible, llevando a la invasión brasileña del norte de Uruguay. Para esto, utilizaré simultáneamente documentos y métodos típicos de la historia política tradicional y de la historia social. Además de la importancia indiscutible de las acciones de los llamados grandes personajes, es preciso reflexionar sobre los significados de las actitudes de hombres y mujeres comunes que habitaban las fronteras. En este sentido, busco también contribuir a la renovación del campo de estudios de historia de las relaciones internacionales, aún muy basado en documentos oficiales. El diálogo entre las dos perspectivas, en la frontera entre la historia social y la historia política, la construcción de la perspectiva de una historia social de las relaciones internacionales me parece fundamental. ${ }^{7}$

Es esta perspectiva la que hace posible la comprensión de la importancia del fenómeno de intenso tránsito de individuos por las fronteras, las fugas de esclavizados, la violencia del reclutamiento de ejércitos y milicias uruguayos y brasileños, los ataques a las comunidades de negros libres y libertos, y principalmente su vulnerabilidad, diariamente sujetos al secuestro y a la esclavización. Es un hecho que esta situación no era nueva en la década de 1840, cuando fue abolida la esclavitud en Uruguay. Pero la combinación de la abolición con la proximidad del fin definitivo del tráfico de africanos para Brasil -en que la

7 Otros autores también han trabajado con una perspectiva semejante, véanse Sparks, Where the Negroes; Mamigonian, Africanos Livres. 
existencia de la esclavitud estuviese siendo cuestionada en aquel país- creó una coyuntura regional totalmente diferente de la anterior, haciendo que los conflictos y tensiones, que hasta entonces eran locales, ganasen una dimensión internacional.

\section{LA ESCLAVITUD EN LAS FRONTERAS DEL PLATA}

Las fronteras políticas de la región del Plata fueron resultado de un largo proceso de colonización y de disputas entre Portugal y España por el dominio de la región del llamado continente del Río Grande y de la cuenca del Río de la Plata, desde la fundación de la colonia del Santísimo Sacramento en 1680. En el siglo XviII, la región fue escenario de constantes disputas entre las dos coronas ibéricas, iniciadas por el Tratado de Madrid de 1750. Los esfuerzos diplomáticos no fueron suficientes para evitar las guerras que, alternadas con periodos cortos de paz, fueron constantes hasta el fin de la década de 1860.

Como en otros lugares, la colonización trajo esclavitud. En la región del Río de la Plata, en la segunda mitad del siglo xviII, la mayor demanda de pieles y charqui para vender en los mercados andino y brasileño trajo un aumento progresivo del número de trabajadores esclavos en las haciendas. En el mismo periodo, en Río Grande del Sur, los esclavos ya eran cerca de 30\% de la población de la capitanía. En las últimas décadas del setecientos, la integración de las economías gaucha y platense a la de Río de Janeiro provocó la llegada forzada de más africanos esclavizados a la región. ${ }^{8}$

8 Entre 1788 y 1824 entraron 10278 esclavos en la provincia de Río Grande del Sur. En el Río de la Plata, según los datos recabados por Alex Borucki, entre 1777 y 1812 se realizaron 712 viajes de negreros en la ruta Brasil, África y Montevideo, con la introducción de al menos 70000 esclavos en la región platense. El impacto de la llegada de estos africanos es el principal hecho demográfico de la región desde el inicio de la colonización ibérica. Según él, la población de Montevideo creció 119\% entre 1791 y 1810, mientras la 
No deja de ser curioso el hecho de que la región pasó a recibir más esclavos africanos justamente entre los siglos XVIII y XIX, cuando el comercio internacional de esclavos comenzaba a ser cuestionado, tanto por las acciones británicas como por el inicio de los movimientos de independencia de las colonias españolas.

Este proceso fue más peculiar en la región que después se convirtió en Uruguay, por estar situada en un área históricamente disputada por portugueses y españoles. Incluso después de la fundación de la ciudad de Montevideo en 1726, la llamada Banda Oriental (por estar situada del lado oriental del Río de la Plata) continuó siendo de hecho portuguesa hasta 1777 cuando, por el tratado de San Ildefonso, España conquistó la mitad sur del actual Uruguay, mientras Portugal mantuvo el norte y las futuras provincias de Río Grande del Sur, Santa Catarina y Paraná.

El primer cuarto del siglo XIX estuvo marcado por disputas entre Portugal y España por el dominio de la región. En 1801, Portugal cambió el control de la colonia de Sacramento, que pasó a España, por la de los Siete Pueblos de las Misiones. Después de la invasión británica de 1806 y 1807 de Buenos Aires y Montevideo y la llegada de la Corte portuguesa a Brasil, en 1808, el gobierno portugués decidió reconquistar el margen izquierdo del Río de la Plata. En la misma época, los movimientos de independencia en la región comenzaron, resultando en la independencia de las Provincias Unidas del Río de la Plata, bajo el liderazgo de Buenos Aires. En 1815, Montevideo era parte del territorio controlado por el argentino Artigas, pero en 1816 pasó

población esclava creció $486 \%$ en el mismo periodo. BORUCKI, "The slave trade". Aparentemente, comerciantes, compradores y autoridades portugueses responsables del tráfico ignoraban deliberadamente el decreto de 1751, según el cual la corte portuguesa prohibía la exportación de esclavos fuera del imperio. Véase "Alvará para que se Não levem negros dos portos do mar para terras que não sejam dos domínios portugueses”, 14 de octubre de 1751. Biblioteca Digital da Câmara dos Deputados, en http://bd.camara.gov.br, consultado el 23 de enero de 2012; Adelman, Sovereignty and Revolution, y Osório, O Império Português. 
nuevamente a control de Portugal, con el nombre de Provincia Cisplatina. Desde entonces, la región estuvo envuelta en disputas contra la presencia argentina. En 1825, con la llamada Guerra Cisplatina, Uruguay inició su movimiento de independencia contra Brasil -cuando, incluso, promulgó una ley decretando el fin del tráfico y la libertad de vientres-, consolidada en $1828 .^{9}$

Hay evidencia de que, por lo menos desde mediados del siglo XviII, había esclavos que cruzaban las fronteras entre los imperios portugués y español en ambas direcciones. En esta época, debido a las Reales Cédulas de 1773 y 1789, el derecho de asilo en tierras españolas, tradición antes limitada a libres (especialmente cristianos e indígenas), fue extendida también a los esclavos que entrasen en su territorio, confiriendo libertad a aquellos que huyesen a esta región. ${ }^{10}$

En 1801, el cartógrafo y naturalista español Félix de Azara mencionó estas fugas, reclamando que los españoles -que, según él, trataban mejor a los esclavos que los portugueses-jamás deberían restituir a los esclavos fugitivos "porque la fuga era un medio lícito de conseguir la libertad, fundado en el derecho natural, contra el que no valía ninguna convención humana”. Escribiendo poco tiempo después, en 1821, el viajero francés Saint Hilaire también haría referencia a las mismas fugas de esclavos de Brasil en dirección al Río de la Plata, afirmando, incluso, que "la protección que Artigas concedía a los negros fugados de la capitanía [de Río Grande del Sur] fueron las razones alegadas para el estallamiento de la guerra" entre españoles y portugueses por el control de la Banda Oriental, iniciada en $1811 .^{11}$

\footnotetext{
9 Véanse Fausto y Devoto, Brasil e Argentina; Palacios y Moraga, La independencia.

10 Isola, La esclavitud.

11 Azara, Memoria; véase también Grinberg, "Illegal Enslavement”, pp. 3152; Saint Hilaire, Viagem ao Rio, p. 65. Saint Hilaire se refería a los conflictos entre los españoles y los portugueses por la Banda Oriental iniciados en 1811. Dando continuidad al movimiento de independencia iniciado el año anterior
} 
El tránsito de esclavos por la frontera sur de Brasil definitivamente preocupaba a las autoridades portuguesas. En 1813, un año después de la prohibición del comercio de esclavos hacia las Provincias Unidas del Río de la Plata, el gobierno portugués reclamaba el decreto que declaraba "ser libre todo y cualquier esclavo de país extranjero que pasare a este territorio por el simple hecho de haberlo pisado", como evidencia la Reclamación del gobierno portugués para la entrega de esclavos refugiados a Brasil en territorio de las Provincias Unidas del Río de la Plata. En ella, los portugueses todavía decían estar inquietos con las fugas de esclavos de la capitanía de S. Pedro del Río Grande del Sur en dirección a los territorios de las Provincias Unidas, que ocurrían en gran número, y amenazaban revisar el armisticio del 26 de mayo de 1812, en el cual Portugal se comprometía a evacuar la orilla izquierda del Río de la Plata. ${ }^{12}$

La cuestión ya había suscitado intercambio de correspondencia entre Portugal y Lord Strangford, ministro británico en la Corte; cartas de él para el gobierno de las Provincias Unidas del Río de la Plata, pidiendo la devolución inmediata de esclavos fugitivos y "fin a los fatales efectos" del decreto. ${ }^{13}$ Después de las amenazas de ambos gobiernos, Buenos Aires respondió revocando el decreto, no sin antes enfatizar en que la prescripción

en Buenos Aires, el general José Artigas sitió la ciudad de Montevideo, donde estaba refugiado el virrey español. Para evitar disturbios políticos cerca de su territorio -y temiendo la posible expansión de Artigas hacia el norte- los portugueses, con el pretexto de liberar al virrey, organizaron un ejército pacificador e invadieron la Banda Oriental, dando inicio a las Guerras Cisplatinas, que sólo terminaron con la independencia de la República Oriental del Uruguay en 1828. Véase Frega, "Caminos de libertad" y Aladrén, "Experiências de liberdade".

12 "Nota del gobierno portugués al de las Provincias Unidas del Río de la Plata", 30 de noviembre de 1813, en "Informe del ministro de relaciones exteriores”, 1857, anexo E, núm. 14, p. 40.

13 "Nota del ministro británico en esta Corte al supremo gobierno de las Provincias Unidas del Río de la Plata”, 27 de noviembre de 1813, en "Informe del ministro de relaciones exteriores”, 1857, anexo E, núm. 15, p. 41. 
de la libertad para todos los esclavos introducidos de países extranjeros por el simple hecho de pisar en su territorio era un reglamento interno, no pudiendo, por esta razón, "dar motivo de queja u ofensa a ningún gobierno extranjero" ${ }^{14}$ En febrero del año siguiente, el gobierno de Buenos Aires volvería al asunto, enfatizando en que, con aquel decreto, ellos no estaban refiriéndose a los esclavos que huyesen de Brasil (que, en estos casos, deberían ser devueltos a sus dueños), sino a aquellos que hubiesen sido "introducidos, por vía de comercio o venta, contra las disposiciones prohibitivas del tráfico de esclavos". ${ }^{15}$

En los 20 años que siguieron a esta discusión, el comercio atlántico de esclavos estaría prohibido tanto en Brasil como en Argentina y Uruguay. Ilegalmente, sin embargo, africanos esclavizados siguieron siendo llevados a la región. En Brasil, las negociaciones entre Inglaterra y el recién creado imperio (1822) acerca del fin del tráfico de esclavos se iniciaron con el proceso del reconocimiento inglés de la independencia de Brasil. En 1826, la convención entre Brasil e Inglaterra sobre el tráfico de esclavos -fraguada por Robert Gordon, embajador británico en la Corte, y el Marqués de Inhambupe, ministro de negocios extranjeros, y refrendada por D. Pedro I- fijaba su abolición en tres años. Cuando el acuerdo antitráfico entre los dos países ya estaba en vigor, fue aprobada la ley de 7 de noviembre de 1831 que, además de prohibir la entrada de esclavos en el país, daba la libertad a los africanos ilegalmente introducidos a partir de entonces, pero no preveía la consideración del contrabando de esclavos como crimen de piratería, como querían los ingleses. Aun así, la ley responsabilizaba criminalmente a

14 "Nota de aquel gobierno al ministro de su majestad británica en esta Corte", 28 de diciembre de 1813, en "Informe del ministro de relaciones exteriores", 1857, anexo E, núm. 16, p. 42.

15 "Nota del gobierno de las Provincias Unidas del Río de la Plata al de S. M. Fidelísima," 1o de febrero de 1814, en "Informe del ministro de relaciones exteriores”, 1857, anexo E, núm. 17, p. 43. 
comerciantes, comandantes y otros trabajadores de los navíos negreros, intermediarios y compradores de africanos esclavizados. Como ya había sido establecido en la convención de 1826, los navíos negreros eventualmente aprehendidos estaban sujetos al proceso y juicio de la Comisión Mixta Brasil-Inglaterra.

A pesar de ser conocida como "ley para los ingleses", hoy hay evidencias suficientes para demostrar que, desde 1826, se acreditaba que el comercio de esclavos sería interrumpido en breve. De ahí la prisa para esclavizar africanos y venderlos en Brasil, el alza general del precio de los esclavos y el aumento del movimiento de navíos negreros que desembarcaron, entre 1826 y 1830, en varias regiones del país. ${ }^{16}$ A mediados de la década de 1830 , con todo, sin que nunca hubiese sido interrumpido -pero el número de africanos importados como esclavos había disminuido drásticamente luego de la promulgación de la ley- el comercio de africanos esclavizados, ahora transformado en contrabando, volvió a crecer.

En Uruguay, el comercio de esclavos hacia la región del Río de la Plata ya estaba siendo atacado desde 1812, cuando fue prohibido por las Provincias Unidas del Río de la Plata. ${ }^{17}$ Mientras, durante la ocupación lusobrasileña en la región, de 1817 a 1828, la introducción de africanos continuó. Durante la Guerra Cisplatina, el gobierno provisional uruguayo decretó, en 1825, el fin del tráfico atlántico de esclavos hacia el país sin gran suceso, ya que la medida no valía ni en Montevideo ni en la colonia del Sacramento, todavía ocupadas por portugueses y brasileños. En 1830, la Constitución uruguaya prohibió el tráfico de esclavos y estableció la libertad de vientres, siguiendo la tendencia de las otras repúblicas latinoamericanas, y a partir de entonces las fechas de 1812 y 1830 fueron consideradas marcos fundamentales

16 Bethell, The Abolition; Grinberg y Mamigonian (coords.), "Para inglês ver?"; Mamigonian, Africanos Livres.

17 BorUCKI, "The slave trade". 
en el proceso uruguayo de abolición de la esclavitud, aunque, en la práctica, el tráfico ilegal continuase con toda fuerza. ${ }^{18}$

En la década de 1830, en vísperas de la Farroupilha (18351845), movimiento separatista gaucho que, por diez años, intentaría proclamar una república riograndense independiente del Imperio de Brasil, y de la Guerra Grande (1839-1851), la guerra civil uruguaya entre los partidos blanco y colorado, la población fronteriza de Uruguay estaba compuesta por muchos brasileños y un gran número de individuos esclavizados que cotidianamente cruzaban la frontera, en general para trabajar, muchas veces por órdenes de sus señores. ${ }^{19}$ Ampliamente integrada a la economía agraria de Río Grande del Sur, la llamada Banda Norte uruguaya también era una región de extensos territorios y baja densidad demográfica. Aunque hubiese brasileños entre los propietarios de tierras hasta las cercanías de Montevideo, la mayoría habitaba en el norte y nordeste de Uruguay, muchas veces en estancias divididas entre los dos lados de la frontera. En varias de estas localidades, como en Tacuarembó, los esclavos llegaron a ser un tercio de la población total, siguiendo el mismo patrón de Río Grande del Sur en esta misma época. ${ }^{20}$

18 El tráfico de esclavos fue nuevamente prohibido en 1839, después ratificado por el tratado anglouruguayo de 1842. Aun así, Montevideo fue observada atentamente por los ingleses, por lo menos hasta la década de 1850. BorUCKI, "The 'African Colonists"”; Borucki, Chagas y Stalla, Esclavitud y trabajo, p. 27; ANDREws, Blakness in the White.

19 Sobre la Revolución Farroupilha véase Pesavento, "Uma certa Revolução”; Guazzelli, “O Horizonte”; sobre la Guerra Grande véase MAIzTEGui Casas, Orientales, vol. 1.

20 Los brasileños en Tacuarembó eran $69.4 \%$ de la población en 1830 y $59.7 \%$ en 1840 . En 1860, 50\% del ganado local pertenecía a brasileños. Al inicio de la década de 1850, de acuerdo con un censo realizado por el gobierno imperial, había 1181 propietarios brasileños en la frontera de Brasil y Uruguay, que sumaban 9 millones de hectáreas pobladas con un millón de cabezas de ganado. Los otros departamentos fronterizos donde había brasileños eran Cerro Largo, Minas y Rocha. PAlermo, “Los afro-fronterizos”, pp. 190-191; Borucki, Chagas y Stalla, Esclavitud y trabajo, pp. 162-163 y 218. 
Semejante concentración de brasileños en el territorio causaba innumerables problemas diplomáticos entre los dos países. El gobierno uruguayo se quejaba de la interferencia brasileña en la política local; charqueadores brasileños presionaban al gobierno riograndense, contrarios a la presencia de estancieros que llevasen el ganado para el lado uruguayo. Quejas de ambos lados resultaron tanto en el aumento del tránsito de personas en la frontera como en la represión -no siempre exitosa- de la transferencia de ganado y, consecuentemente, de esclavos de Río Grande del Sur hacia Uruguay. ${ }^{21}$ Si la inestabilidad política de ambos lados de la frontera ya contribuía al aumento de tensiones locales, las proclamaciones de abolición de la esclavitud en Uruguay que siguieron transformarían toda la región, literalmente, en un polvorín.

\section{LA GUERRA Y LA ABOLICIÓN}

DE LA ESCLAVITUD EN URUGUAY

La guerra civil por el control político del país que enfrentó a los blancos, liderados por Manuel Oribe, con los colorados de José Fructuoso Rivera, despertó la sensación de desorganización social en la región fronteriza, con incursiones militares de lado a lado, robo de ganado y caballos y apropiación generalizada de esclavos para componer las tropas. A mediados de 1842, con la retirada de Rivera y el avance de Oribe hacia Montevideo, el gobierno colorado, aliado de Brasil, pasó a necesitar desesperadamente hombres para formar sus tropas de defensa. En un primer momento, el gobierno uruguayo determinó el sorteo de esclavos para el servicio militar; los dueños de aquellos esclavos sorteados recibirían 300 pesos por cada uno, mientras que estos recibirían inmediatamente su carta de libertad, con la obligación de servir en el ejército por cuatro años. Quizá porque

${ }_{21}$ Petiz, Buscando a liberdade, p. 41. 
la medida no fue suficiente, seguramente por presiones internas, en diciembre de aquel año el gobierno colorado decidió abolir la esclavitud.

Dueños y esclavos, incluso brasileños, fueron notificados inmediatamente de la nueva ley que solicitaba pronto alistamiento de aquellos aptos para el servicio militar. Como la medida afectaba principalmente a los señores brasileños que tenían propiedades en la Banda Oriental, esta generó intensas reclamaciones por parte de los propietarios riograndenses. Estos intentaron retirar sus esclavos del país, mientras contaban con la ayuda de funcionarios de Río Grande del Sur y del gobierno brasileño, escondiendo los esclavos en las embarcaciones de guerra brasileñas.

Pero el reclutamiento de esclavos no fue una medida adoptada sólo por Rivera. Luego de que se estableció en territorio oriental, instalando el gobierno en Cerrito, Oribe también utilizó el alistamiento forzado de esclavos para llenar su ejército. La ley de abolición de 1846 no menciona explícitamente el reclutamiento, pero éste también era su objetivo. Algunos días después de su promulgación, autoridades de Cerrito se apresuraron a incorporar a los ahora libertos a las tropas blancas, antes de que los dueños brasileños regresaran con sus esclavos a su país. Estos recibieron la promesa de una indemnización en "tiempo oportuno", pero en el año de 1847 las reclamaciones de propietarios brasileños sobre la devolución de esclavos comenzaron a aumentar. La mayoría de los propietarios no obtuvo respuestas satisfactorias del gobierno de Cerrito, que se rehusaba, incluso, a entregar esclavos fugitivos que estuviesen sirviendo en su ejército.

A pesar de la retórica humanitaria utilizada en las dos proclamaciones de abolición de la esclavitud, la colorada de 1842 y la blanca de 1846, es imposible comprenderlas fuera del contexto bélico. En ambos casos, la abolición fue la única manera de los gobiernos en guerra de aumentar el contingente de tropas, ya 
que propietarios uruguayos y brasileños se oponían al alistamiento de esclavos, incluso con promesas de indemnización. A los ojos de los dueños y del gobierno brasileño, el reclutamiento era un claro incentivo para la fuga de esclavos de Río Grande del Sur. Para completar el cuadro, se rumoraba la noticia de que el gobierno de Uruguay pretendía instigar al representante inglés a mandar las embarcaciones británicas a capturar las brasileñas que llevaran esclavos. Rumor o no, el miedo que éste causó en el encargado de negocios de Brasil en Montevideo fue incontestable. En diciembre de 1842, luego de la abolición, temiendo "insultos" por parte de los ingleses, más empeñados en la represión del tráfico atlántico de esclavos, y con el objetivo de salvar la propiedad esclava de los súbditos del imperio, fueron transportados en la corbeta Siete de Abril más de 200 esclavos en dirección a la provincia brasileña de Santa Catarina. ${ }^{22}$

Lo mismo ocurrió en 1846. También en este caso, el gobierno brasileño insistía en que las medidas implantadas por la república incentivaban la fuga de esclavos. Lo que, de hecho, acontecía. La frase del gobierno uruguayo "el negro pasó de cosa a hombre porque podía cambiársele esa condición; y sin gran injusticia no puede volver al estado de esclavitud" fue perfectamente entendida por los esclavos de la frontera que, conscientes de lo que significaba llegar a territorio uruguayo, empezaron a huir con más frecuencia. 23

Las reclamaciones de autoridades de Río Grande del Sur sobre fugas de esclavos se intensificaron en 1848, cuando el presidente de la provincia solicitó a los delegados de policía de los municipios localizados cerca de la frontera que calculasen el número de esclavos fugados para reclamar formalmente su devolución a los uruguayos. La solicitud del presidente de la provincia generó varias listas con relaciones de esclavos fugitivos,

22 Borucki, Chagas y Stalla, Esclavitud y trabajo, p. 221.

23 Borucki, Chagas y Stalla, Esclavitud y trabajo, p. 44. 
elaboradas a partir de las respuestas enviadas por los señores a las delegaciones. Se estima que, en 1850, oficialmente 900 esclavos huyeron a Uruguay. Incluso con las intensas reclamaciones, las devoluciones no ocurrieron. Aun en medio del trastornado contexto de la Guerra Grande, parte de los fugitivos se integró a las comunidades negras del norte de Uruguay, mientras otra parte se presentó a las fuerzas policiales y militares del ejército uruguayo voluntariamente, como forma de inviabilizar el retorno a Brasil. ${ }^{24}$

El decreto blanco de abolición afectó especialmente a los propietarios brasileños de la frontera. Como sus propiedades estaban situadas en territorio del gobierno de Cerrito, muchos no consiguieron impedir que sus esclavos huyesen de sus dominios, ni que fuesen confiscados por las tropas blancas. Esta situación perduró por lo menos hasta el fin de la guerra civil, y contribuyó a empeorar las relaciones diplomáticas entre el gobierno del imperio y el de Cerrito, más hostiles con cada nueva denuncia de confiscación de tierras, ganado y esclavos. ${ }^{25}$

La hostilidad de los blancos aumentaba a medida que los brasileños intervenían en la guerra civil a favor de los colorados. El actuar brasileño fue decisivo para la victoria de los colorados en 1851 -y para la consolidación de la hegemonía brasileña en la región- expresada en los cinco tratados impuestos a Uruguay: el Tratado de la Perpetua Alianza, en el cual Uruguay daba a Brasil el derecho de intervenir en sus conflictos internos;

24 AHRGS, Correspondencia de gobernantes, paquete 21, informe de la repartición de los negocios extranjeros presentada a la Asamblea General Administrativa (1850). Las listas originales están en el AHI, "Misiones diplomáticas brasileñas”, 310/1/1 (1848). Estas listas han sido ampliamente analizadas por la historiografía de Rio Grande do Sul. Véase Petiz, Buscando a liberdade, pp. 53-54; Caratti, O solo da liberdade, pp. 100-103; Carvalho, "Em solos fronteriços”, pp. 111-128; Flores, Crimes de Fronteira.

25 Para un cuadro general de la política internacional en la Plata en ese periodo, y de las relaciones diplomáticas entre Argentina, Brasil, Paraguay y los gobiernos blanco y colorado de Uruguay, véase Ferreira, O Rio da Prata. 
el Tratado de Comercio y Navegación, por el cual permitía la navegación en el río Uruguay y sus afluentes, y exentaba de impuestos aduanales a Brasil en la exportación de charqui y ganado vivo; el Tratado de Socorro, en el cual Uruguay reconocía sus deudas con Brasil; el Tratado de Límites, por el cual Uruguay renunciaba a sus pretensiones territoriales al norte del río Quaraí y reconocía a Brasil el derecho exclusivo de navegación en la laguna Merín y el río Yaguarón, fronteras naturales entre los dos países. Además de estos, también figuraba el tratado de extradición de criminales y esclavos fugitivos.

Si los tratados como un todo fueron ampliamente rechazados por la opinión pública uruguaya -hasta porque entraron en vigor sin aprobación de la Asamblea Legislativa-, la parte relativa a la devolución de esclavos fue especialmente criticada. En los términos del acuerdo, se establecía que aquellos que pasaran por la frontera de Brasil y Uruguay sin el consentimiento de sus señores pudieran ser reclamados, tanto por el gobierno brasileño como por los propios señores, y devueltos al territorio brasileño. ${ }^{26}$ Este fue motivo, de queja abierta de André Lamas, cónsul plenipotenciario en Brasil, a su amigo Paulino José Soares de Souza, futuro vizconde de Uruguay. En la práctica, el tratado significaba el rechazo brasileño a las leyes de abolición uruguayas -en ese momento, justamente por la oposición a Brasil- transformadas en fundamento de la nacionalidad uruguaya. ${ }^{27}$

No sería sólo con Uruguay que Brasil trataría de firmar tratados de devolución de esclavos. A semejanza del primero, fueron firmados otros con Perú, en 1851, con Argentina en 1857 (este también nunca refrendado por el Congreso de aquel país), además de negociaciones con Bolivia, Venezuela y hasta

26 Grinberg, "Slavery, manumission and the law”, pp. 401-411.

27 Sobre la relación entre la abolición y el nacionalismo uruguayo en la década de 1840, véase CAÉ, “Escravidão e liberdade”. 
Ecuador a fines de la década de 1850 e inicios de la de 1860. Defendiendo la hegemonía en la región, el Imperio de Brasil asumió su "presencia activa" en las relaciones diplomáticas de América del Sur. ${ }^{28}$ En todos los tratados, los gobiernos de las repúblicas sudamericanas debieron reconocer el principio de devolución de esclavos pertenecientes a súbditos brasileños que hubiesen cruzado la frontera contra la voluntad de sus amos. Ambas partes se comprometían a no reclutar desertores de otros países para impedir justamente la fuga de esclavos o libertos reclutados. ${ }^{29} \mathrm{~A}$ diferencia de los tratados de extradición de esclavos existentes entre los imperios coloniales de las Américas, estos fueron establecidos entre Brasil, nación esclavista, y países que ya habían abolido la esclavitud.

Evidentemente, la noción de "suelo libre" no fue una creación del siglo XIx. El concepto tiene una historia mucho más compleja y extensa. Como notó Max Weber, las localidades municipales medievales, en la Europa continental, desarrollaron costumbres en las cuales los siervos conquistaban sus libertades de acuerdo con el principio stadtluft macht frei (literalmente, el aire de la ciudad libera). ${ }^{30}$ Desde 1569 la esclavitud fue considerada inconsistente con la tradición jurídica británica; en esta ocasión, en el caso Cartwright, un siervo importado de Rusia fue considerado libre por las autoridades porque "el aire inglés

${ }^{28}$ Ferreira, O Rio da Prata; Caldeira, “Cativos asilados”, pp. 115-141; SANTOS, O Império.

29 “Tratado entre el señor D. Pedro II, emperador de Brasil, y la República Oriental de Uruguay para la entrega recíproca de criminales y desertores, y para la devolución de esclavos, firmado en Río de Janeiro en 1851 y ratificado por parte de Brasil en 13 del mismo mes y por la referida república en 4 de noviembre de dicho año", artículos VI y VII, en Sistema Consular Integrado, Actos Internacionales, ministerio de relaciones exteriores, Brasil, en línea: http://dai-mre.serpro.gov.br/atos-internacionais/bilaterais/1851/b_26/ consultado el 9 de octubre de 2013.

30 Weber, The City. 
es muy puro para ser respirado por esclavos". ${ }^{31}$ El proceso sentó un precedente importante en la legislación inglesa, ya que fue usado como argumento en casos ocurridos con esclavos llevados de las colonias británicas del Caribe a Inglaterra durante el siglo XVIII. A fines de aquel siglo, la discusión sobre el estatus de James Somerset, un esclavo fugitivo de Jamaica, cerró definitivamente la cuestión en Inglaterra al establecer que, en ausencia de leyes positivas sobre la esclavitud, todas las personas que pisaran suelo inglés deberían ser consideradas libres. ${ }^{32}$ En Francia, los tribunales en los siglos XVII y XVIII también aceptaron la máxima según la cual "Todas las personas son libres en este reino; y si un esclavo cruza las fronteras de este lugar, siendo bautizado, se hace liberto". ${ }^{33}$ Así, cuando las cortes parisinas se vieron en la necesidad de definir el destino de los esclavos llevados por sus señores de las colonias francesas del Caribe, acabaron liberando centenas de esclavos que llegaban a la capital.

Ya en el siglo xIx, en el caso de Estados Unidos, el principio de suelo libre fue rechazado por la decisión de la Suprema Corte, en 1857, en el famoso caso Dred Scott. ${ }^{34}$ En vez de aceptar que los estados libres de la Unión crearan regiones de suelo libre -y, por lo tanto, desnaturalizar el propio concepto de esclavitud-, Estados Unidos optó por institucionalizar el concepto de raza como componente esencial de la ciudadanía americana. Ligada a la raza, la esclavitud, allí, no era una condición-que, como tal,

\footnotetext{
31 Higginbotham JR., In the Matter of Color, p. 321.

32 Finkelman, An Imperfect Union; Fenrenbacher, Slavery, Larw, Politics; OAKES, Slavery and Freedom.

33 Peabody, "There Are No Slaves in France", p. 31.

${ }^{34}$ En este caso, el esclavo Dred Scott reclamó su libertad en el estado esclavista de Missouri por haber acompañado a su señor a los estados libres de Illinois y Wisconsin. A pesar de que los tribunales de Missouri decidieron el caso en favor de Scott, la Suprema Corte concluyó que Scott, siendo un hombre negro, no era ciudadano de Estados Unidos y no podía iniciar una acción legal ni comparecer en los tribunales. FeHrenbacher, The Dred Scott Case.
} 
podía ser modificada- sino un atributo del cual los individuos no podían escapar. La interpretación sudamericana de este principio fue muy diferente de la estadounidense. $\mathrm{Al}$ reconocer la premisa de que el territorio crea derechos, las repúblicas sudamericanas instituyeron criterios de ciudadanía en los cuales la condición de ciudadanos era dada por el lugar de nacimiento, no por atributos inmutables como el color o la ascendencia.

En el caso específico de Uruguay, la abolición de la esclavitud y la consiguiente definición del territorio nacional como suelo libre, incluso en el contexto bélico de la guerra civil, acabaron transformándose en elementos definitorios de la soberanía nacional, en oposición a la presencia brasileña tenida como expansionista y eslavista.

\section{LOS INTERESES DE LOS PROPIETARIOS BRASILEÑOS EN URUGUAY Y LA PROHIBICIÓN DEL TRÁFICO \\ DE AFRICANOS HACIA BRASIL}

La firma de los tratados entre Brasil y Uruguay el 12 de octubre de 1851 inauguró un nuevo momento en la forma como la esclavitud era entendida por los dos países. El tratado de extradición se enfocó específicamente en las situaciones de los esclavos que pasaron al territorio uruguayo sin permiso de sus amos. Incluso en el mismo año, pero reconociendo el derecho brasileño a los esclavos fugitivos e impidiendo la entrada al país de esclavos procedentes de Brasil, el gobierno colorado de Uruguay resistió aceptar la búsqueda de esclavos en su territorio, excepto por aquellos expresamente incluidos en el tratado, como se percibe en la circular del 6 de diciembre:

$1^{\circ}$ Está absolutamente prohibido introducir bajo ningún pretexto en cualquier punto de la República individuo alguno que no tenga certificado de libertad, hasta que reunido el Cuerpo Legislativo adopte sobre el particular una resolución que juzgue conveniente. 
$2^{\circ}$ No se devolverán más los esclavos fugitivos que hayan entrado al territorio de la República después del 4 de Noviembre [próximo pasado].

$3^{\circ}$ La reclamación será atendida cuando fuese hecha por el Presidente de la Provincia de Río Grande del Sur siendo los esclavos de súbditos Brasileños establecidos en dicha Provincia, por el dueño del esclavo, o por quien lo represente debidamente autorizado...

$4^{\circ}$ La reclamación deberá ser acompañada de títulos o documentos que según las leyes de Brasil sirvan para probar la propiedad que se reclama.

$\mathrm{Al}$ año siguiente, una reclamación del gobierno uruguayo declaraba que individuos tenidos como esclavos fugitivos en Brasil y que hubiesen entrado a Uruguay antes de la fecha de ratificación del tratado de 1851 no deberían ser considerados fugitivos. Si acaso lo fuesen, no serían devueltos. Incluso, según la misma nota, el señor no podría más, por cuenta propia o mandando otro en su lugar, invadir el territorio uruguayo para capturar a sus supuestos esclavos. ${ }^{35}$ Es evidente que la insistencia en recordar las reglas del tratado demostraba lo frecuentes que eran estas invasiones, -lo que continuaría aconteciendo por toda la década de 1850 e inicios de la de 1860-. Los propietarios brasileños no sólo continuaban (y continuarían) rechazando abiertamente la ley argumentando siempre que, si aceptaban las leyes uruguayas, se quedarían sin mano de obra. Muchas veces contaban con la complicidad abierta de las autoridades brasileñas, que interpretaban la regla de manera muy particular.

Reclamaciones de ambas partes resultaron, algunos años después, en un acuerdo entre los dos gobiernos: los brasileños podrían llevar a sus antiguos esclavos como trabajadores

35 Brasil, Informe del año de 1851 presentado a la Asamblea General Legislativa, ministerio de relaciones exteriores, 1852, s/p. en Brasil, Ministerial Reports (1821-1960): relaciones exteriores http://brazil.crl.edu/bsd/bsd/u1489/ contents.html. Consultado el 25 de enero de 2018. 
contratados a Uruguay, apoyados por los referidos certificados de libertad. Como José Maria da Silva Paranhos, el propio ministro brasileño residente en Montevideo, se autoelogió más tarde, los contratos de trabajo utilizados en suelo uruguayo fueron una salida genial, ya que pudieron:

Por fin consentir que los Brasileños pudiesen de un modo lícito suplir con sus esclavos la escasez de brazos que se sentía y todavía se siente en la República: y volviéndose así innecesario el empleo clandestino de esclavos, al paso que se evitaba la violación de las leyes de la República, se concurría para alimentar el trabajo de sus estancias, y se promovía la libertad de muchos individuos, que de otra manera permanecerían en cautiverio. ${ }^{36}$

La supuesta solución genial de Paranhos acabó siendo poco eficaz. Consultas enviadas por autoridades fronterizas brasileñas a sus superiores demuestran que las dudas respecto de la condición jurídica de los trabajadores de la frontera permanecían $-y$ con ellas las tentativas de interpretar las leyes a favor de los propietarios brasileños.

Este fue el caso del subdelegado de Santana del Libramiento, pequeño municipio brasileño localizado en la frontera con Uruguay, que en 1856 envió una consulta a Manuel Vieira Tosta, futuro Barón de Muritiba, entonces presidente de la provincia de San Pedro Grande del Sur: él quería saber si serían liberados los esclavos que "por cualquier circunstancia fortuita" traspasasen la frontera -digamos que en busca de algún animal que, también despistado, pasase al territorio de la república-o los que habitaban haciendas situadas exactamente en la línea de la frontera, con tierras en ambos lados, o aquellos

${ }^{36}$ AGNU, Ministerio de Relaciones Exteriores, Legación del Uruguay en el Brasil, c. 102, carp. 124, "Nota del gobierno Imperial Brasileño a la legación de la República Oriental del Uruguay en Brasil”, 27 de abril de 1857. 
que, estando contratados en Uruguay, pasaren a la provincia de Río Grande del Sur.

La interpretación de Tosta fue que, estando la provocación muy cerca de la frontera, no podían ser considerados libertos los esclavos que, en servicio doméstico, traspasasen la misma. Incluso, los esclavos que quisiesen permanecer bajo estas circunstancias, en vez de ser considerados libertos, serían tenidos como fugitivos. Por regla general, concluía el presidente de la provincia, sólo cuando el esclavo fuese obligado por su señor a prestar servicio en territorio vecino podría ser considerado liberto, no incluyendo nunca el hecho de hallarse ahí momentáneamente contra la voluntad de su amo, pues en estos casos excepcionales no se podría aplicar el principio de que la libertad de suelo libera al esclavo que lo toca. Él también consideraba que no deberían ser liberados aquellos que habitaban propiedades con tierras en ambos países: "pues en ese caso la continuidad de la propiedad territorial importaba la continuidad de su jurisdicción doméstica". Sólo deberían ser considerados libres los esclavos que, estando contratados o en servicio autorizado por sus dueños en territorio vecino, volviesen a Brasil. ${ }^{37}$

Relacionado con los intereses de los dueños de la frontera, la interpretación del presidente de la provincia de Río Grande del Sur sobre la condición jurídica de aquellos que traspasaban la línea que separaba el suelo esclavo del suelo libre era bastante simple; en la duda, se mantenía al individuo como esclavo. El problema era que, como en el sur todos bien sabían, en Río de Janeiro, capital del Imperio de Brasil, el entendimiento acerca de esta situación era diferente.

Esto puede ser percibido mediante otra consulta, esta vez al Consejo de Estado, hecha por Eusébio de Queiroz, entonces

37 Brasil, Informe del año de 1856 presentado a la Asamblea General Legislativa, ministerio de relaciones exteriores, 1857, s/p., en Brasil, Ministerial Reports (1821-1960): relaciones exteriores http://brazil.crl.edu/bsd/bsd/u1489/ contents.html. consultado el 25 de enero de 2018. 
presidente del Tribunal de Relación de Río de Janeiro. Él preguntaba si "un esclavo residente en país extranjero puede entrar al Imperio y ser no sólo conservado en esclavitud, sino mandado entregar a su señor por la justicia de su país". La motivación fue la llegada a la Relación de un caso de un esclavo que cometió un crimen, cuyo dueño vivía en Uruguay. El parecer del Consejo de Estado, en una decisión considerada memorable, venía con las siguientes conclusiones:

$1^{\circ}$ La de que la ley de 07.11.1831 no tuviera sólo el propósito de acabar con el tráfico de negros nuevos, sino de disminuir el número de esclavos en Brasil y, también, el de los libertos por ley;

$2^{\circ}$ La de que su disposición comprendía, indudablemente, el caso del esclavo que, con el consentimiento de su amo, hubiese pasado a país extranjero y de ahí reentrado al Impero. ${ }^{38}$

La decisión recibió duras críticas de los dueños residentes en la provincia de Río Grande del Sur. Para ellos, al no considerar estos aspectos resultantes de la situación de frontera, las autoridades imperiales se estarían comprometiendo con un peligrosísimo principio de desapropiación. En Río de Janeiro, los miembros del Consejo de Estado reconocieron la importancia de confirmar el principio de derecho internacional según el cual el esclavo que pisase suelo libre adquiría el derecho a la libertad. Pero con las protestas de los propietarios y del presidente de la provincia de Río Grande del Sur, la decisión de 1856 no sólo continuó en vigor sino que fue refrendada en 1858 por una nueva consulta hecha por el presidente de la provincia de Río Grande del Sur al Consejo de Estado.

Esta vez, el caso trataba sobre esclavos hipotecados en Brasil que habían sido llevados por su dueño a territorio uruguayo. Para enojo de los propietarios de la frontera, el parecer, firmado

38 Aviso 188 del 20 de mayo de 1856, en Soares, Campanha Jurídica, p. 7. 
por el ministro de negocios extranjeros y aprobado por el emperador, decía así:

El esclavo ignora las transacciones de que es objeto, no entra, no puede entrar en su examen, obedece a su señor. Si éste lo trae al Estado Oriental, cualesquiera que sean las obligaciones contraídas, haya o no hipotecas, por aquel simple hecho, el esclavo adquiere su libertad, es libre en esta república [de Uruguay], es liberto en Brasil. Ambos gobiernos están obligados a mantener el derecho que le concedieron, ninguno puede reclamar su devolución, ninguno puede concederla. Esta interpretación es tan exacta que el gobierno imperial [en caso anterior] determinó lo siguiente: Finalmente deben ser considerados libertos los esclavos que, estando como contratados, o en servicio autorizado por sus señores en el territorio indicado, volvieran a la provincia de Río Grande del Sur, por cuanto, por el principio general arriba expuesto, el hecho de permanecer o haber permanecido bajo consentimiento de su señor en un país donde está abolida la esclavitud da inmediatamente al esclavo la condición de liberto. ${ }^{39}$

¿Cómo entender la posición de las autoridades del Imperio de Brasil? Considerando estas decisiones, el gobierno del Imperio no sólo no refrendaba las decisiones tomadas por la presidencia de la provincia de Río Grande del Sur, sino que reprobaba las actitudes de los propietarios locales -justo esos que se consideraban los defensores de las fronteras brasileñas al sur del paí-. Para comprender mejor esta aparente paradoja, es preciso regresar a la coyuntura política brasileña en las décadas de 1840 y 1850.

Desde mediados de decenio de 1840, la retórica diplomática brasileña acerca de los conflictos en el Plata tenía como lema la

${ }^{39}$ AHI, Parecer del Concejo de Estado del 20 de marzo de 1858, BrasilUruguay. Extradición de esclavos, 5/58 (1858), en Brasil, Secretaría de Estado de Negocios del Imperio y Extranjeros, el Concejo de Estado y la Política Externa del imperio, pp. 31-35. 
defensa de la independencia y soberanía de Uruguay. Una vez perdida la Provincia Cisplatina, era fundamental asegurar que Uruguay no se volviera una de las Provincias Unidas del Río de la Plata. Al final, para los arquitectos de la política externa brasileña en la región, el papel de Brasil había sido esencial para firmar la existencia independiente tanto de Uruguay como de Paraguay frente al supuesto expansionismo argentino. ${ }^{40}$

El problema es que gran parte de la fundamentación de la soberanía de Uruguay estaba asentada en el principio de libertad, concretada por la abolición de la esclavitud en la década de 1840. Más precisamente: en la diferenciación entre Brasil, imperio esclavista, y Uruguay, república de la libertad. No reconocer esto significaría concordar con la acusación, común en Montevideo, de que los tratados de 1851 habían llevado a Uruguay de vuelta a la condición de Provincia Cisplatina. Así, no era bien visto que Brasil, con sus intenciones de controlar la diplomacia de la región del Plata, figurase formalmente como interventor en las cuestiones internas de otro país. André Lamas, cónsul plenipotenciario de Uruguay en Río de Janeiro, sabía bien que las autoridades brasileñas no podían sustentar el discurso de crítica al expansionismo argentino si fuesen, al mismo tiempo, acusadas de expandir las fronteras de la esclavitud más allá de sus límites territoriales. Principalmente porque, en el plano de las relaciones diplomáticas brasileñas del inicio de la década de 1850 , no había tema más sensible que el tráfico de esclavos.

Empero, desde la reapertura ilegal del tráfico de esclavos en la década de 1830, Brasil había sido presionado por Inglaterra a adoptar medidas efectivas para su extinción. Fue a partir de 1845, con el Slave Trade Suppression Act (o Aberdeen Bill), en el cual los ingleses se autoconferían el derecho de prender cualquier navío sospechoso de transportar africanos esclavizados en el océano Atlántico, que el comercio transatlántico de africanos

40 Ferrerira, O Rio da Prata, p. 226. 
pasó a ser más enfáticamente reprimido. En 1849, Inglaterra movilizó parte de su escuadra a Brasil. Como resultado, enero de 1850 fue el mes con mayor número de aprensiones de navíos negreros en el país desde el inicio de las inspecciones en el mar. En los meses siguientes, navíos de guerra británicos atacaron embarcaciones sospechosas en el litoral norte de Río de Janeiro y en Paranaguá, al sur de la costa de São Paulo. Al inicio de julio, llegaron a Río de Janeiro relatos de combates entre los británicos, que incendiaron dos embarcaciones, y los brasileños, que, con miedo de las inspecciones inglesas, abrieron fuego y hundieron sus propios navíos. Se decía entonces que la Marina británica no dudaría en bombardear la propia Corte. Aunque intereses diversos concurriesen para la decisión del gobierno brasileño de finalmente extinguir el tráfico de africanos esclavizados, es innegable que la inquietud causada por las acciones inglesas fue fundamental para el compromiso brasileño de abolirlo en septiembre de 1850.

Era por eso que la Corte debía mostrar respeto y obediencia a los acuerdos internacionales, no sólo para que Brasil consiguiese ocupar la posición de mediador regional de conflictos que anhelaba, sino para garantizar la defensa de su propia soberanía nacional en relación con Inglaterra, que dudaba, con toda razón, del compromiso del gobierno brasileño de acabar con el tráfico atlántico de esclavos. La correspondencia entre británicos y brasileños después de la promulgación de la ley del 4 de septiembre de 1850 muestra que los ingleses temían que, así como en 1831, esta ley también pasase a ser letra muerta. Y no estaban equivocados. Por lo menos hasta 1855, todavía eran constantes los intentos de desembarque de africanos en las bahías y ensenadas de la costa brasileña. ${ }^{41}$

Como bien sabían las autoridades brasileñas, aquella tensa coyuntura exponía claramente la fragilidad internacional del

${ }^{41}$ Bethell, The Abolition; Carvalho, “O desembarque”, pp. 223-260. 
Imperio. Era imposible, en el contexto atlántico de abolición internacional del tráfico de esclavos y de la emancipación de los esclavos, que un país pretendiera tener una posición hegemónica regional si seguía atendiendo las demandas esclavistas de los propietarios (que incluían los pedidos de devolución de aquellos que huían a otros países).

Así, la Corte de Río de Janeiro parecía estar en una encrucijada: por un lado, tenía que garantizar el respeto a los tratados y leyes internacionales, principalmente en lo referente al tráfico de esclavos, que Brasil era continuamente acusado de violar; por otro, no era posible olvidar que el control y la protección de las fronteras nacionales en una región estratégica estaban a cargo precisamente de aquellos que defendían la expansión de la esclavitud más allá de las fronteras nacionales.

Si esto no fuese suficiente, todavía estaba el fantasma de la revolución farroupilha, el movimiento dominado por gauchos contra el Imperio que culminó en la proclamación de la República Río-Grandense en 1836. Derrotado en 1845, ni por eso el movimiento acabó con las insatisfacciones de los locales, reincorporados al Imperio de Brasil. Al contrario, para muchos de estos, como el Impero no defendía sus intereses, ellos tenían el derecho de actuar por cuenta propia. En las llamadas "californias", hasta grandes propietarios invadían el territorio uruguayo, buscando recuperar ganado y esclavos perdidos. ${ }^{42}$

Uruguay, si ya era destino de esclavos fugitivos desde la doble abolición de la esclavitud, pasó, en la década de 1850, a ser invadido por capitaẽs do mato en busca de personas que esclavizar y vender en Río Grande del Sur. El contexto, al final, no pudo

\footnotetext{
42 En 1850 Francisco Pedro Buarque de Abreu, Barón de Jacuí, organizó la mayor incursión armada para recuperar ganado y bienes en Uruguay, habiendo reclutado un pequeño ejército de 300 hombres pagado a su costa. Reclamaciones de la República Oriental del Uruguay contra el gobierno de Brasil, p. xiii. Véase también Torres, O Visconde de Uruguai, pp. 79-85; Lima, A nefanda pirataria de carne; Palermo, "Secuestros y tráfico".
} 
ser más propicio. El fin del tráfico atlántico de africanos hacia Brasil en 1850 provocó un gran incremento en los precios de los esclavos, incluso mayor del que ya venía ocurriendo desde la década de 1820. No había señales de que la demanda de esclavos hubiese disminuido en el país; muy al contrario. ${ }^{43}$ Una nueva frontera de esclavización, es eso lo que las comunidades negras del norte de Uruguay se volvieron para los señores y capitaés do mato de la frontera. ${ }^{44}$

\section{LA NUEVA FRONTERA DE ESCLAVIZACIÓN}

A fines de 1853, Juan Rosa, su mujer Juana Rosa y su hija Segundina Marta, de casi 4 años, comparecieron ante el cónsul uruguayo de la ciudad de Río Grande para pedir ayuda y contar que habían sido secuestrados por Laurindo José da Costa. Laurindo y sus secuaces habían aparecido en casa de Juan Rosa diciendo que tenían orden del gobierno de Uruguay para "reunir a todos los hombres de color y a los que fuesen casados con mujeres e hijos", por eso ellos se habían dejado amarrar y llevar. En el trayecto, Laurindo continuó raptando a otras personas y asesinando a aquellos que ofreciesen resistencia. Al llegar a Pelotas, Juan Rosa, Juana Rosa y Segundina Marta fueron vendidos a un francés, pero consiguieron huir y llegar al consulado uruguayo. ${ }^{45}$

$\mathrm{Al}$ año siguiente, la africana Rufina y sus cuatro hijos tuvieron un destino semejante. Secuestrados por la misma cuadrilla en Tacuarembó, en Uruguay, fueron llevados a Brasil y vendidos. Rufina consiguió llamar la atención de la policía brasileña y

\footnotetext{
43 Florentino, "Sobre minas"; Salles, E o Vale.

44 El concepto de frontera de esclavización es entendido aquí como lo formuló Joseph Miller y ha sido ampliamente utilizado por la historiografía africanista, Miller, Way of Death.

45 APERGS, I Ramo Civil y Crimen, paquete 57, proceso 2914, 1854. Regina figuró en el proceso como Reina Rodríguez.
} 
denunciar el crimen. El delito fue reportado y debatido por periodistas en Porto Alegre y cónsules uruguayos e ingleses. En el transcurso del proceso, el entonces ministro de Relaciones Exteriores de Brasil, Paulino José Soares de Souza, recibió correspondencia del ministro de Relaciones Exteriores de Inglaterra, Lord Palmerston, tomando medidas contra este "tráfico de nueva especie" que estaba siendo practicado en las fronteras brasileñas. Rufina no sólo fue liberada; consiguió reunir a su familia y regresar a Uruguay. ${ }^{46}$

Desde 1852, acusaciones similares venían siendo hechas por personas que recurrían a la policía brasileña, cónsules de Uruguay y hasta a representantes consulares ingleses con la misma cuestión: habían sido secuestrados en Uruguay para ser vendidos como esclavos en Brasil. De acuerdo con la documentación al respecto, la mayoría estaba compuesta de mujeres y niños. Repetían el patrón de esclavización ilegal observado en tantas otras regiones en este mismo periodo.

Sobre este nuevo tipo de tráfico, las autoridades de Río Grande del Sur estaban más que bien informadas. Sólo entre 1849 y 1853, la justicia de la provincia lidió con siete casos de este tipo, todos originados de denuncias de cónsules uruguayos. ${ }^{47}$ Los crímenes de la cuadrilla de Laurindo José da Costa eran de conocimiento público, como muestra la noticia publicada en 1854 en el periódico O Rio-Grandense, que, a su vez, la transcribía del Correio do Sul. Ya era la segunda vez que los periódicos hacían mención de un crimen cometido por él. ${ }^{48}$ Acerca del secuestro de Rufina y sus hijos, André Lamas, ministro plenipotenciario uruguayo en Brasil, escribió al ministro Limpo de Abreu que

\footnotetext{
46 APERGS, I Ramo Civil y Crimen, paquete 88, proceso 3368, $1855 . \mathrm{He}$ analizado este caso en Grinberg, "The Two Enslavements", pp. 259-290.

47 Sobre los procesos existentes véase el catálogo de APERGS, documentos de la esclavitud: procesos crimen-el esclavo como víctima o reo.

48 O Rio Grandense, 15 de junio de 1854. Véase también Lima, "A nefanda pirataria de carne", pp. 145-146.
} 
esperaba que las autoridades brasileñas hiciesen su parte, de acuerdo con "el derecho de gentes y los convenios internacionales, la legislación del Imperio y las leyes especiales contra la piratería y el abominable tráfico e introducción de esclavos". ${ }^{49}$

Las reclamaciones de Lamas eran recibidas en Brasil en la misma época en que el tráfico atlántico de esclavos todavía funcionaba ilegalmente en la provincia. En Brasil, en 1852, centenas de africanos fueron desembarcados precipitadamente en la costa de Tramandaí, después de que el navío encalló en la región. ${ }^{50}$ Cerca de dos años después, Vereker, cónsul inglés en Porto Alegre, llamaba la atención del presidente de la provincia Cansansão de Sinimbu sobre un posible nuevo desembarque de africanos en el litoral gaucho. Aunque este último insistiese que todo no pasaba de rumor, escribió al ministro de negocios exteriores aseverando no haber habido ningún desembarque en la costa gaucha y reiterando que nada guardaría "para evitar al gobierno el disgusto de que se practique en esta provincia [de Río Grande del Sur] un crimen tan contrario a las Leyes y a la Civilización, y que el mismo gobierno tanto se empeña en castigar". ${ }^{51}$

Toda la correspondencia intercambiada en los primeros años de la década de 1850 entre los varios cónsules ingleses en Brasil y las autoridades brasileñas muestra que la cuestión del tráfico estaba lejos de ser resuelta. Para los ingleses, la venta de africanos introducidos en Brasil después de 1831, cuyas varias denuncias ocuparon buena parte de la correspondencia intercambiada en 1854 entre Howard, cónsul británico en la Corte, y el ministro de relaciones exteriores Limpo Abreu, las tentativas de desembarques de africanos en las costas brasileñas y los secuestros de

\footnotetext{
49 AGNU, fondo Legación, c. 106, núm. 70, oficio de 8 de julio de 1854.

${ }^{50}$ Las autoridades provinciales se movilizaron para aprehender a los africanos nuevos, pero la mayoría de ellos fue apropiada por residentes del litoral y muchos fueron encaminados a la "cima de la sierra". Véase Moreira, "Boçais e malungos”, y Oliveira, De Manoel Congo.

51 AHRGS, Oficios reservados, A2-10, núm. 3, oficio de 27 de agosto de 1854.
} 
negros en la frontera sur significaban la misma cosa: la continuidad del tráfico ilícito de personas. ${ }^{52}$ No es por nada que, en aquel año, Vereker escribió en su informe anual a Lord Clarendon, ministro de relaciones exteriores de Inglaterra, que debería

[...] ser reconocido que las leyes de Brasil, conforme al estado presente, son totalmente insuficientes para prevenir lo que puede ser llamado un tráfico interno de esclavos ilícito, quiero decir, la venta como esclavas de personas negras que no son esclavas ni de acuerdo con las leyes brasileñas. Para mostrar que este tráfico existe parece ser apenas necesario referir al hecho de que, comparativamente, pocos de los negros importados de África desde la promulgación de las leyes brasileñas que declaraban que estas personas deberían ser consideradas libres, tuvieron desde entonces sus libertades reconocidas; es también de conocimiento general que esclavos son frecuentemente robados de sus propietarios para ser vendidos; parece evidente que, si las leyes brasileñas fuesen eficientes para impedir el tráfico interno de esclavos, las ventas de esclavos por personas que no fuesen sus dueños [...] no podrían tener lugar, y menos todavía el secuestro de personas libres para ser vendidas como esclavas. ${ }^{53}$

La correspondencia diplomática y las reclamaciones eran muchas veces reproducidas en los informes del ministerio de negocios extranjeros de Brasil, evidenciando la preocupación brasileña en reconocer la existencia de los casos y, principalmente, sus esfuerzos en reprimirlos. En 1859, por ejemplo, el ministro de Relaciones Exteriores aludió a la reclamación de Uruguay del "robo de personas de color para ser vendidas" en Río Grande del Sur. En uno de los casos citados, una casa había sido asaltada por dos brasileños, que se habían llevado un infante de tres años; en otro, habían "sido robados en las

52 NA, Foreign Office 84, códices 942-944, 1852-1854.

53 NA, Foreign Office 84, códice 944, oficio de 30 de junio de 1854, ff. 133 y ss. 
proximidades de Aceguá dos menores de color, que después fueron vendidos como esclavos en Río Grande", cuyos familiares reclamaban ahora "o su rescate o devolución". El ministro decía incluso que "se verificó en parte esta denuncia, y uno de los menores, que había sido vendido con el nombre de Domingos y declaró llamarse João Serapio, fue judicialmente depositado en la villa de Piratinim". ${ }^{4}$ En 1860, el informe del Ministerio de Relaciones Exteriores reportaba que:

El jefe político del departamento del Salto informa al gobierno de haber sido substraídos por D. Marcellino Ferreira, súbdito brasileño, de un establecimiento de campo, de su propiedad y llevados a Brasil a fin de ser vendidos ahí como esclavos, la negra Carlota y cuatro hijos menores de color, nacidos en la República, de los cuales el más pequeño tenía apenas cinco meses [...] Habiendo regresado en seguida al territorio de la República, donde fue aprehendido por la autoridad competente, declaró que efectivamente había llevado a aquellas personas al territorio brasileño con la intención de venderlas como eslavas, ofreciendo hacer su devolución en pocos días [...] lejos de cumplir esa promesa [...] Marcellino Ferreira consiguió escaparse en 29 de agosto último de la prisión en que estaba detenido, y burlar la vigilancia de la policía en su tránsito hasta la frontera. ${ }^{55}$

Cada año, cuanto más frecuente era la acción de propietarios y capitaẽs do mato en su territorio, más aumentaba el tono

${ }^{54}$ Brasil, Informe del año de 1859 presentado a la Asamblea General Legislativa, Ministerio de Relaciones Exteriores, 1860, en Brazil Ministerial Reports (1821-1960), p. 92, en línea: http://brazil.crl.edu/bsd/bsd/u1489/contents. html. Consultado el 25 de enero de 2018.

${ }^{55}$ Brasil, Informe del año de 1860 presentado a la Asamblea General Legislativa, Ministerio de Relaciones Exteriores, 1861, s/p, en Brazil Ministerial Reports (1821-1960), Relaciones Exteriores, en línea: http://brazil.crl.edu/bsd/ bsd/u1489/contents.html. Consultado el 25 de enero de 2018. 
de denuncia de ingleses y uruguayos. Como declaró en 1860 José Vásquez Sagastume, diputado por el departamento de Tacuarembó,

[...] la ciudadanía oriental se está extinguiendo en el Norte del Río Negro: que contra lo expreso de la Constitución de la República y lo establecido por la libertad de nuestras leyes, la esclavitud es un hecho en algunas partes [...] En esa localidad tan importante de la República puede decirse que ya no hay Estado Oriental: los usos, costumbres, el idioma, el modo de ser, todo es brasileño: puede decirse, como continuación de Río Grande del Sud.56

Andrés Lamas, ministro plenipotenciario de Uruguay en Brasil, repetía la denuncia: "En el momento en que, por cualquiera circunstancia, le conviene al poseedor de la persona de color, le hace trasponer la frontera $-\mathrm{y}$ transpuesta, cae el mentiroso y audaz disfraz con que se han burlando las leyes de la Repúblicay la desamparada víctima vuelve á asumir su pública condición de esclavo". ${ }^{57}$

Así como en relación con los esclavos fugitivos, el Imperio brasileño respondía a estas acusaciones reafirmando la severa represión a cualquier tentativa de burlar la prohibición del tráfico de esclavos. En 1861, en su informe, el ministro de relaciones exteriores de Brasil enfatizaba que "el gobierno imperial ha llamado la atención del presidente de la provincia de San Pedro de Río Grande del Sur sobre el robo de menores de color en el Estado Oriental, con el fin de ser vendidos en Río Grande como esclavos". ${ }^{58}$ Y garantizaba que en los casos de esclavización

\footnotetext{
56 Lima, A nefanda pirataria de carne, p. 74.

57 Lima, A nefanda pirataria de carne, p. 51.

${ }^{58}$ Brasil, Informe del año de 1861 presentado a la Asamblea General Legislativa, Ministerio de Relaciones Exteriores, 1862, s/p, en Brazil Ministerial Reports (1821-1960), Relaciones Exteriores, p. 54, en línea: http://brazil.crl. edu/bsd/bsd/u1489/contents.html. Consultado el 25 de enero de 2018.
} 
ilegal "las autoridades brasileñas han perseguido y llevado a los tribunales del país a algunos de los inculpados". ${ }^{59}$

La declaración era una verdad a medias. Aunque fiscales distribuidos por varios municipios de Río Grande del Sur habían, de hecho, procesado a algunos de los acusados del crimen de "reducir personas libres a la esclavitud", de los 68 procesos existentes al respecto en el Archivo Público de Río Grande del Sur, prácticamente ningún sospechoso fue condenado. Alegando estar tratando de recuperar esclavos fugitivos, desconociendo la condición de libre o liberto de aquellos que secuestraban, la mayoría fue absuelta por el juzgado local. ${ }^{60}$ Además de eso, aunque en algunos casos el cónsul inglés Howard quedó aparentemente convencido de los esfuerzos brasileños en reprimir el tráfico, como escribió en 1855 a Clarendon, entonces ministro de Relaciones Exteriores de Inglaterra, es difícil que la retórica brasileña haya convencido a los uruguayos de la eficacia de la represión al secuestro de negros. ${ }^{61}$ En reclamación dirigida al Vizconde de Maranguape en 1857, en la cual describía todas las denuncias y procesos ocurridos en los últimos tres años, el ministro uruguayo no dudaba en afirmar que los secuestradores brasileños se acreditaban absolutamente seguros de propia impunidad, seguros de la que las autoridades brasileñas cubrirían sus crímenes; él por eso solicitaba al gobierno brasileño rápida actuación para reprimir esta "piratería organizada y ejercida en gran, sorprendente escala”. ${ }^{62}$

${ }_{59}$ Brasil, Informe del año de 1861 presentado a la Asamblea General Legislativa, Ministerio de Relaciones Exteriores, 1862, s/p, en Brazil Ministerial Reports (1821-1960), Relaciones Exteriores, p. 50, en línea: http://brazil.crl. $\mathrm{edu} / \mathrm{bsd} / \mathrm{bsd} / \mathrm{u} 1489 /$ contents.html. Consultado el 25 de enero de 2018.

60 Sobre esto véase Grinberg y Mamigonian, "Le crime de réduction".

${ }^{61}$ NA, Foreign Office 84, códice 969, oficio de 30 de junio de 1855.

${ }^{62}$ Oficio del 9 de octubre de 1857, en Reclamaciones de la República Oriental del Uruguay contra el Gobierno de Brasil, Montevideo, El País, 1864, Anexo 11. 


\section{LA ESCALADA EN LAS TENSIONES}

Los años que siguieron evidenciaron el aumento gradual de las reclamaciones de ambas partes, que ahora también incluían atentados contra la vida y la propiedad de brasileños en Uruguay. Cuando José Antonio Saraiva llegó a Montevideo, en mayo de 1864 , el tono de las reclamaciones y denuncias de violencia entre ambas partes ya era ensordecedor. En abril del año anterior, en oposición al gobierno blanco de Berro, el general colorado Venancio Flores había desembarcado con correligionarios en Rincón de las Gallinas, pequeño poblado uruguayo frente a la frontera con Argentina, dando inicio a otra guerra civil contra los blancos. A pesar de que la Corte imperial, en Río de Janeiro, había recomendado a los propietarios brasileños que respetasen la neutralidad a la cual Brasil se había comprometido, ellos inmediatamente apoyaron a Flores, juntando caballos, provisiones y dinero para las tropas rebeldes. Los señores brasileños de la frontera, sintiéndose desasistidos por el gobierno brasileño, vieron en el líder colorado la posibilidad de librarse de los blancos, de acabar con los "asesinatos, violencias y robos" que imperaban en la región y, finalmente, de acabar con las restricciones a la forma como empleaban a sus trabajadores en el lado uruguayo de sus propiedades.

De hecho, desde 1861, aumentó el número de reclamaciones brasileñas, todas registradas en los informes del ministro de negocios exteriores. ${ }^{63}$ La situación llegó a un punto que, en noviembre de 1863, el general Antonio de Souza Neto, líder local desde la época de la revolución farroupilha, fue a Río de Janeiro a avisar al gobierno que "no era prudente dejar que Río Grande

63 Schneider, A Guerra; los informes pueden consultarse en Brazil Ministerial Reports (1821-1960), Relaciones Exteriores, en línea: http://brazil.crl.edu/ bsd/bsd/u1489/contents.html. Consultado el 25 de enero de 2018 . 
se entregue a sí mismo”, socorriendo "por cuenta propia a sus hermanos". La amenaza era clara:

No desconocía el gobierno imperial, acrecentaba Neto, las consecuencias que han de venir de la actitud independiente de los ríograndenses; bastará el llamado de algún exaltado para poner en armas a miles de hombres, que tratarán, si no en nombre del gobierno, ciertamente en nombre de Brasil, de inculcar a los orientales el respeto debido a un vecino poderoso. ${ }^{64}$

El tono de Neto luego hizo eco en la Cámara de Diputados; en sesión del 5 de abril de 1864, varios diputados tomaron como propias las quejas del gaucho y defendieron que "el gobierno imperial emplease los medios necesarios para oponerse a la carnicería de ciudadanos brasileños en el Estado Oriental". ${ }^{65}$ Las discusiones en Río repercutieron también en el sur: mientras en Montevideo se propagaba el rumor de que D. Pedro II quería reanexar la antigua provincia cisplatina, en Río Grande del Sur los propietarios acreditaban que el Imperio no aseguraría a sus ciudadanos "condición segura de existencia tranquila”.

Fue temiendo el inicio de una nueva convulsión política en Río Grande del Sur que el gobierno imperial decidió enviar a Saraiva a Montevideo en misión especial para negociar las demandas brasileñas con el gobierno blanco. La misión, descrita en Brasil como “enteramente pacífica”, fue acompañada de la distribución de tropas en la frontera y de cinco navíos de guerra anclados en el Plata para "apoyar las negociaciones" de Saraiva. ${ }^{66}$

En sus instrucciones, el ministro de negocios exteriores de Brasil, João Pedro Dias Vieira, había explicado a Saraiva que él no debería abandonar la política de neutralidad que hacía tanto

${ }^{64}$ SCHNeIDER, A Guerra, p. 33.

65 SCHNeIDER, A Guerra, p. 32.

66 SchneIder, A Guerra, p. 34. 
tiempo caracterizaba el actuar brasileño en la región del Plata. Su acción consistiría en insistir en la defensa de la vida, honra y propiedad de los brasileños en Uruguay que venían sufriendo "crímenes atroces y bárbaros tan repetidamente ahí practicados desde 1851 hasta ahora, para no remontar a tiempos más lejanos".67

Y así lo hizo Saraiva, incluso sabiendo que no había simpatía posible de los uruguayos de la capital por los brasileños de la frontera. Incluso los relatos de la época, francamente favorables a la intervención brasileña, destacaban el interés de abogados y periodistas de Montevideo en promover una "nivelación democrática", haciendo "sentir a esos señores, en su aislamiento aristocrático, que en una república no puede haber sino absoluta igualdad de derechos". ${ }^{68}$ Así, al llegar a Uruguay, en vez de entregar directamente el ultimátum brasileño, apeló inicialmente al ministro de relaciones exteriores de aquel país, pidiendo sensibilidad del gobierno uruguayo en una situación que "el gobierno Imperial no puede prever, ni podrá tal vez evitar el efecto de su repercusión, si para remover las causas indicadas no contribuye la República con fuerza y decisión". ${ }^{69}$ Era una amenaza velada. A la carta se seguían detalles de las 63 reclamaciones formales hechas por el gobierno del imperio al uruguayo en los últimos 12 años. Ellas trataban de ataques a propiedades, asesinatos, robos de ganado, tentativas de obligar a brasileños al servicio militar.

Juan José Herrera, ministro de relaciones exteriores uruguayo, reaccionó con ironía: ¿ con cerca de 40000 brasileños residentes al norte del país, la cifra de 63 reclamaciones en 12 años sería relevante? Si los brasileños sufriesen tanto en Uruguay, ¿no se habrían mudado ya y regresado al Imperio de Brasil? Incluso

${ }^{67}$ AHI, Carta de 20 de abril de 1864, misión Saraiva, ff. 835-837.

68 Schneider, A Guerra, p. 25.

69 "Carta de José Antonio Saraiva al ministro de Relaciones Exteriores de Uruguay, Montevideo, 18 de mayo de 1864”, en Documentos diplomáticos. Misión Saraiva, p. 17. 
considerándolas igualmente "recriminaciones inoportunas", mucho más significativas serían las 48 reclamaciones uruguayas, venidas de una población de centenas, no miles, de personas.

Para Herrera, las reclamaciones de ambas partes no podían ser razón de apoyo de los brasileños a la invasión del colorado Venancio Flores, toda vez que sus partidarios no eran los que residían en Uruguay, sino en Brasil. El motivo del apoyo de los "piratas de frontera" brasileños tenía nombre: las "californias", que continuaban ocurriendo al norte del país. Era la posibilidad de saquear el territorio uruguayo que motivaba la acción de ese "caudillismo bárbaro", "dueño y señor irresponsable de esos territorios, centro de amenaza permanente contra la civilización", que no respetaba ni las propiedades de los brasileños residentes en la región. ${ }^{70} \mathrm{Al}$ defender a Neto y sus cómplices, acusó Herrera, el Imperio brasileño optaba por abandonar a sus propios súbditos residentes en Uruguay. Al final de su larga carta a Saraiva, Herrera presentó, también en detalle, las reclamaciones uruguayas al Imperio de Brasil, todas, según él, desatendidas o sin respuesta. De las 48, 33 versaban sobre esclavización de negros, mujeres y niños en su mayoría, para ser vendidos como esclavos en Brasil. Entre 1853 y 1863, fueron decenas de familias secuestradas por cuadrillas brasileñas, la mayoría de ellas conocidas por las autoridades locales. Varias reclamaciones citan nominalmente a la cuadrilla de Laurindo José da Costa. Los uruguayos describieron con detalle las ocurrencias, citando la ciudad de destino de los esclavizados y, en algunos casos, hasta los nombres de sus compradores. ${ }^{71}$

70 "Carta de José Antonio Saraiva al ministro de Relaciones Exteriores de Uruguay, Montevideo, 18 de mayo de 1864”, en Documentos diplomáticos. Misión Saraiva, p. 17.

71 De las 48 reclamaciones 33 versan directamente sobre la esclavitud; 10 sobre otros asuntos como servicio militar, asesinatos y robo de ganado. Otras 5 son reclamaciones poco detalladas sobre invasiones a propiedades, incluso de brasileños, que pudieron resultar también en esclavizaciones ilegales. 
Ofendido con la respuesta de Herrera, días después Saraiva escribió en un oficio confidencial a la Corte que el gobierno oriental lo sorprendió, haciendo "recriminaciones amargas, apreciaciones inexactas de los acontecimientos, poca benevolencia y delicadeza en la manera de producir las quejas que alega contra el Imperio”. Y completó: “Es urgente organizar y distribuir nuestra fuerza en la frontera" ${ }^{72}$

El desenlace de la historia es conocido. Después de una temporada de negociaciones en Buenos Aires, donde fraguó la alianza con los argentinos y los colorados uruguayos, con la aprobación de Thornton, representante inglés en el Plata, Saraiva regresó a Montevideo. El 4 de agosto de 1864, entregó a Herrera el ultimátum que desde abril traía consigo, dando el plazo de seis días para atender las exigencias brasileñas. Al recibir la negativa del presidente uruguayo Aguirre, Saraiva dio por terminada su misión y se retiró del país. En poco más de dos meses, tropas brasileñas invadieron el norte de Uruguay. Como escribiría Joaquim Nabuco algunos años después, "de la de Uruguay procede la guerra con Paraguay y de ésta, la Triple Alianza”. ${ }^{73}$

\section{CONCLUSIÓN: “LO QUE NO ES SECRETO \\ NO SE PUEDE DESCUBRIR”}

Creo haber dejado claro el principal argumento de este texto: es imposible comprender plenamente la invasión brasileña a Uruguay en 1864 y la gran guerra que le sucedió sin considerar las tensiones y los incidentes diplomáticos iniciados a partir de la abolición de la esclavitud en Uruguay. Claro que no se pretende implicar que hay una causa única a un conflicto de tal magnitud, e ignorar las desavenencias relativas a impuestos sobre la

Reclamaciones de la República Oriental del Uruguay contra el Gobierno de Brasil.

72 Documentos diplomáticos. Misión Saraiva, pp. 25-26.

73 Nabuco, Um Estadista, p. 508. 
propiedad de ganado, la delimitación de fronteras y la disputa más amplia por la hegemonía política en el Plata. En términos generales, los argumentos presentados aquí refrendan la tesis de que la Guerra de Paraguay fue motivada por la construcción y consolidación de los Estados Nacionales en el Río de la Plata. ${ }^{74}$ Sucede que la esclavitud -su defensa en Brasil, su abolición en Uruguay y después en Argentina- fue central en este proceso $y$, con raras excepciones, ésta no figura en las interpretaciones al respecto.

No deja de ser intrigante el silencio de las autoridades y la historiografía sobre el asunto. Muy ofendido con la publicación de las reclamaciones uruguayas, el enviado especial José Antonio Saraiva se negó a discutirlas, ni siquiera las menciona en su correspondencia con la Corte. El contenido de las reclamaciones nunca fue enunciado directamente por los políticos brasileños, ni por aquellos que, como el oficial del gabinete del Ministerio de Negocios Extranjeros João Batista Calógeras, criticaron severamente el desenlace de la misión Saraiva:

Toda nuestra política sobre la cuestión fue infeliz desde el origen. Comenzamos por enviar una misión especial, llevados por una amenaza de revolución de los río-grandenses que apoyaban a Flores [...] fuimos a exigir la satisfacción de reclamaciones que habíamos abandonado hacía doce años, mientras el Estado oriental tenía otras tantas cosas contra nosotros, una verdadera provocación..$^{75}$

Arriesgo formular algunas razones para comprender mejor este silencio. La primera de ellas se refiere a la elaboración de la narrativa oficial sobre el inicio de la guerra, escrita al calor de los acontecimientos. Durante toda su carrera política, Saraiva debió defenderse de las críticas de que su misión había sido

\footnotetext{
74 Véase la nota 4.

${ }^{75}$ Carvalho, “Um ministério”, p. 65, énfasis mío.
} 
un fracaso, que él no había sido capaz de evitar el inicio de un conflicto que se convirtió en el Vietnam brasileño. Para eso, era esencial definir dos puntos: en primer lugar, que había sido gracias a su diplomacia que las negociaciones con los argentinos fueron exitosas, llevando a la formación de la Triple Alianza; en segundo, que la guerra de hecho había sido iniciada con la invasión de Paraguay a Mato Grosso y no con la brasileña a Uruguay. Disociando los conflictos como si de hecho fuesen dos, no sólo Saraiva sino todo el gobierno brasileño, se eximió de la responsabilidad de haber iniciado la catástrofe que fue la Guerra del Paraguay.

Sólo estas construcciones narrativas hacen posible la comprensión de la frase de Nabuco de que Brasil desempeñó en la guerra "el papel de representante desinteresado de la civilización y de la libertad en América del Sur”. Y más: para él, Saraiva “fue verdaderamente el portador del nuevo mensaje de paz y buena voluntad entre brasileños y argentinos. La fatalidad de su misión consistió en que "la guerra [...] resultaba necesariamente de la militarización despótica de Paraguay, y habría, tarde o temprano, de estallar, desde que el delirio de López se pronunciase [...] Están felizmente fuera de duda los orígenes de la guerra del Paraguay" ${ }^{76}$

Las motivaciones políticas del monarquista Joaquim Nabuco al elaborar su versión de la historia son hasta comprensibles. Monarquista liberal, amigo personal de Saraiva, él ayudaba a construir en la década de 1890, poco después de la proclamación de la República (1889), una imagen positiva acerca del pasado reciente del imperio, incluyendo hasta la abolición de la esclavitud, obra del abolicionismo y de la familia real brasileña. Más difícil es entender las razones de la miopía historiográfica brasileña que, en los muchos análisis del periodo, no parece haberse interesado en ir más allá de la narrativa elaborada en el siglo xIx para

76 Nabuco, Um Estadista, pp. 507-508. 
explorar las causas del conflicto entre uruguayos y brasileños y el acercamiento de las tensiones en la frontera.

Tal vez, hasta hace poco tiempo los historiadores se habían fiado de más de autores como el prusiano Schneider, consejero del káiser de Prusia y corresponsal de la Nueva Gazeta Prusiana, autor de A Guerra da Tríplice Aliança contra o governo da República do Paraguai (1864-1870), publicado en 1875 con notas de José Maria da Silva Paranhos Junior, barón de Río Blanco. Él sugirió que ningún periodo de la larga guerra "que surgió de estas complicaciones en el Estado Oriental exige tan minuciosa consulta a la correspondencia diplomática como su principio, que fue, digámoslo así, el preámbulo o el pretexto para la gran lucha que le siguió". ${ }^{77}$ No hay ninguna duda sobre la importancia documental de la correspondencia diplomática brasileña; pero al enfocarse sólo en su análisis, sin incorporar el intercambio de cartas entre políticos y agentes consulares de Uruguay, Brasil e Inglaterra, se tiene una versión apenas parcial de los acontecimientos. Para profundizar nuestro conocimiento al respecto, es preciso hacer justamente lo contrario: superar las narrativas nacionales.

En el caso de Brasil, una de las consecuencias de la narrativa nacional corriente es la concepción de los ejes de la política externa del país en el siglo XIX y de las relaciones con Inglaterra y la región del Plata de manera absolutamente apartada. El tráfico de esclavos ocuparía una posición destacada en la primera y, una vez superada la cuestión, en 1850, Brasil se habría podido dedicar a la segunda. Ahora, como se vio, nada más lejos de la realidad: no sólo el tráfico de esclavos continuó siendo el punto neurálgico de las relaciones entre brasileños e ingleses a lo largo de toda la década de 1850 e inicio de la de 1860, como también fue el punto esencial para la construcción de las relaciones internacionales entre Brasil y sus vecinos del Plata -y quizá de toda América del

77 SchneIder, A Guerra, p. 72. 
Sur-. Las discusiones en torno a la prohibición del tráfico de africanos y de la abolición de la esclavitud, de hecho, conectan estos dos ejes, de forma que uno sólo es comprensible a la luz del otro.

Empero, para entender la centralidad de la esclavitud en todos los ámbitos de las relaciones internacionales brasileñas en el siglo xix, es preciso llevar la investigación más allá de la correspondencia diplomática. Al final, lo que se revela en la lectura de las cartas e informes escritos por diplomáticos es también aquello que se esconde. En 1864, con las relaciones diplomáticas con Inglaterra rotas justamente por más de una década de intentos brasileños de resistir la abolición del tráfico internacional de africanos esclavizados, las acusaciones uruguayas de secuestro de negros y la esclavitud ilegal fueron un asunto a callar. Y, realmente, todos lo hacían. Ni los brasileños, a quienes no interesaba el debate internacional público de esta cuestión, ni al grupo del colorado Venancio Flores, que tomó el poder a principios de 1865 con ayuda brasileña y construyó la versión oficial de la narrativa uruguaya. De hecho, las reclamaciones uruguayas parecen haberse ahogado con el gobierno blanco de Berro.

Pero el silencio cómplice de ministros y embajadores y otros grandes personajes de la historia política internacional no resiste a la lectura de los documentos producidos en el día a día. Como también han mostrado otros tantos historiadores uruguayos y brasileños, muchos de ellos habitantes de la frontera, que han investigado en los últimos años la correspondencia local de gobernadores y presidentes de la provincia y agentes consulares, listas de fugas, asientos de bautismo, diarios, inventarios y procesos criminales, las cuestiones relativas a la esclavitud fueron tantas y $\tan$ recurrentes que, para todos los que vivían en aquella época, no eran secreto alguno, y "lo que no es secreto no se puede descubrir". ${ }^{78} \mathrm{Al}$ aproximar el foco a lo cotidiano de mujeres

78 Esta cita es la espina dorsal del libro $A$ bipótese bumana de Alberto Mussa Romance policial ambientado en Río de Janeiro en 1854. Aunque 
y hombres que vivían en la frontera entre Brasil y Uruguay, es muy posible que estemos, sólo ahora, descubriendo aquello que era evidente para los contemporáneos.

Sobre este punto de vista, es innegable que las actitudes de las personas que huían, resistían a los secuestros en la frontera y se hacían oír en las delegaciones y los tribunales tuvieron un impacto tremendo. En aquel contexto, sus voces repercutieron lejos. Más porque venían acompañadas de todas aquellas otras que, sin conseguir escapar de la esclavización, desaparecieron sin dejar rastro, y no lograron dejar sus historias de vida preservadas en los archivos.

Traducción de Jorge E. Delgadillo Núñez

\section{SIGLAS Y REFERENCIAS}

AGNU Archivo General de la Nación, Montevideo, Uruguay.

AHI Archivo Histórico do Itamaraty, Río de Janeiro, Brasil.

AHRGS Archivo Histórico de Río Grande del Sur, Porto Alegre, Brasil. APERGS Archivo Público del Estado de Río Grande del Sur, Porto Alegre, Brasil.

NA National Archives [Archivos Nacionales], Londres, Inglaterra.

Adelman, Jeremy, Sovereignty and Revolution in the Iberian Atlantic, New Jersey, Princeton University Press, 2006.

Aladrén, Gabriel, “Experiências de liberdade em tempos de guerra: escravos e libertos nas Guerras Cisplatinas (1811-1828)”, en Estudos Históricos, 22 (2009), pp. 439-458.

Andrews, George R., Blackness in the White Nation: A History of AfroUruguay, Chapel Hill, University of North Carolina Press, 2010.

APERGS, Documentos da escravidão: processos crime-o escravo como vítima ou réu, Porto Alegre, Companhia Rio-Grandense de Artes Gráficas, 2010.

usándola aquí fuera de su contexto original, lo hago pensando que la esclavitud era justamente ese secreto que, de tan conocido por todos los que vivieron en esa época, no era necesario descubrir. 
Azara, Felix, Memoria sobre el estado rural del Río de la Plata y otros informes, Madrid, Imprenta de Sánchez, 1847.

Barroso, Vera Lucia M. (coord.), Raízes de Santo Antônio da Patrulha e Caraá, Porto Alegre, EST, 2000.

Betancur, Arturo, Alex Borucki y Ana Frega (coords.), Estudios sobre la cultura afro-rioplatense, Montevideo, Facultad de Humanidades y Ciencias de la Educación, 2004.

Bethell, Leslie, The Abolition of the Brazilian Slave Trade: Britain, Brazil, and the Slave Trade Question, Cambridge, Cambridge University Press, 1970.

Borucki, Alex, "The slave trade to the Río de la Plata, 1777-1812: Trans-Imperial Networks and Atlantic Warfare”, en Colonial Latin American Review, 20 (2011), pp. 81-107.

Borucki, Alex, "The 'African Colonists' of Montevideo. New Light on the Illegal Slave Trade to Rio de Janeiro and the Río de la Plata (1830-1842)", en Slavery and Abolition, 30 (2009), pp. 427-444.

Borucki, Alex, Karla Chagas y Natalia Stalla, Esclavitud y trabajo: un estudio sobre los afrodescendientes en la frontera uruguaya, 1835-1855, Montevideo, Pulmón, 2004.

Brasil, Secretaria de Estado dos Negócios do Império e Estrangeiros, $O$ Conselho de Estado e a política externa do Império: Consultas da Seção dos Negócios Estrangeiros: 1858-1862, Río de Janeiro, CHDD; Brasilia, FUNAG, 2005.

CAÉ, Rachel da Silveira, "Escravidão e liberdade na construção do Estado Oriental do Uruguai. (1830-1860)," tesis de maestría en historia, Río de Janeiro, Universidade Federal do Estado do Rio de Janeiro, 2012.

Caldeira, Newman di Carlo, "Cativos asilado", en Secreto y Gomes (coords.), 2017, pp. 115-141.

Caratti, Jonatas Marques, O solo da liberdade: as trajetórias da preta Fanstina e do pardo Anacleto pela fronteira rio-grandense em tempos do processo abolicionista uruguaio (1842-1862), São Leopoldo, Oikos, Editora Unisinos, 2013.

Carvalho, Marcus, "O desembarque nas praias: o funcionamento do tráfico de escravos depois de 1831”, en Revista de História, 167 (2012), pp. 223-260. 
Carvalho, Marcus, “Em solos fronteriços”, en Grinberg (coord.), 2013, pp. 111-128.

Documentos diplomáticos. Mision Saraiva, Montevideo, Imprenta de "La Reforma Pacifica”, 1864.

Doratioto, Francisco, Maldita Guerra: nova história da Guerra do Paraguai, São Paulo, Companhia das Letras, 2002.

Fausto, Boris y Fernando Devoto, Brasil e Argentina: um ensaio de história comparada (1850-2002), São Paulo, Editora 34, 2004.

Fehrenbacher, Don, Slavery, Law, Politics: The Dred Scott Case in Historical Perspective, Oxford, Oxford University Press, 1981.

Fehrenbacher, Don, The Dred Scott Case: Its Significance in American Law and Politics, Oxford, Oxford University Press, 1979.

Ferreira, Gabriela Nunes, O Rio da Prata e a Consolidação do Estado Imperial, São Paulo, Hucitec, 2006.

Finkelman, Paul, An Imperfect Union: Slavery, Federalism, and Comity, Chapel Hill, University of North Carolina Press, 1981.

Florentino, Manolo, "Sobre minas, crioulos e a liberdade costumeira no Rio de Janeiro, 1789-1871”, en Tráfico, cativeiro e liberdade-Rio de Janeiro, séculos XVII-XIX, Río de Janeiro, Civilização Brasileira, 2005.

Flores, Mariana, Crimes de Fronteira: a criminalidade na fronteira meridional do Brasil (1845-1889), Porto Alegre, Edipucrs, 2014.

Frega, Ana, “Caminos de libertad”, en Betancur, Borucki y Frega (coords.), 2004.

Grinberg, Keila, “Illegal Enslavement, International Relations, and International Law on the Southern Border of Brazil", en Law and History Review, 35 (2017), pp. 31-52.

Grinberg, Keila, "Slavery, manumission and the law in nineteenth-century Brazil: reflections on the law of 1831 and the 'principle of liberty' on the southern frontier of the Brazilian Empire", en European Review of History/ Revue Europeene d'bistoire, 16 (2009), pp. 401-411. 
Grinberg, Keila, "The Two Enslavements of Rufina: slavery and international relations on the Southern Border of Nineteenth Century Brazil", en The Hispanic American Historical Review, 96 (2016), pp. 259-290.

Grinberg, Keila (coord.), As fronteiras da escravidão e da liberdade no sul da América, Río de Janeiro, 7Letras, 2013.

Grinberg, Keila y Beatriz Mamigonian (coords.), “Dossiê 'Para inglês ver?’ Revisitando a Lei de 1831”, en Estudos Afro-Asiáticos, 29 (2007), pp. 90-340.

Grinberg, Keila y Beatriz MAMigonian, "Le crime de réduction à l'esclavage dans le Brésil du XIx e siècle", en Brésil(s). Sciences bumaines et sociales, 11 (2017), http://journals.openedition.org/bresils/2138, DOI: 10.4000/bresils.2138, consultado el 25 de enero de 2018.

Grinberg, Keila y Ricardo Salles (coords.), Brasil Imperial, Río de Janeiro, Civilização Brasileira, 2009, 3 volúmenes.

Guazzelli, Cesar, “O Horizonte da Província: a República Rio-Grandense e os Caudilhos do Rio da Prata (1835-1845)", tesis de doctorado en historia, Río de Janeiro, Universidade Federal do Rio de Janeiro, 1998.

Higginbotham JR., Leon, In the Matter of Color: Race and the American Legal Process: The Colonial Period, Oxford, Oxford University Press, 1978.

Isola, Ema, La esclavitud en el Uruguay de sus comienzos hasta su extinción (1743-1852), Montevideo, Publicaciones de la Comisión Nacional de Homenaje al Sesquicentenario de los Hechos Históricos de 1825, 1975.

Izecksohn, Vitor, Slavery and War in the Americas: Race, Citizenship, and State Building in the United States and Brazil, 1861-1870, Charlottesville, University of Virginia Press, 2014.

Lima, Rafael Peter, “A nefanda pirataria de carne humana': escravizações ilegais e relações políticas na fronteira do Brasil meridional (1851-1868)", tesis de maestría en historia, Porto Alegre, Universidade Federal do Rio Grande do Sul, 2010.

Maiztegui CASAs, Lincoln R., Orientales: una historia politica del Uruguay, Montevideo, Planeta, 2004, vol. 1.

Mallo, Silvia C. e Ignacio Telesca (coords.), "Negros de la patria”: los afrodescendientes en las luchas por la independencia en el antiguo virreinato del Río de la Plata, Buenos Aires, SB, 2010. 
Mamigonian, Beatriz, Africanos Livres: a abolição do tráfico de escravos no Brasil, São Paulo, Companhia das Letras, 2017.

Miller, Joseph, Way of Death: Merchant Capitalism and The Angolan Slave Trade, 1730-1830, Wisconsin, University of Wisconsin Press, 1996.

Moreira, “Boçais e malungos”, en BArroso (coord.), 2000.

Nabuco, Joaquim, Um Estadista do Império: Nabuco de Araújo, sua vida, suas opiniões, sua época, Río de Janeiro, Topbooks, 1997 [1899].

OAKes, James, Slavery and Freedom: An Interpretation of the Old South, Nueva York, Vintage, 1990.

Oliveira, Vinicius Pereira, De Manoel Congo a Manoel de Paula: Um africano ladino em terras meridionais, Porto Alegre, EsT Edições, 2006.

Osório, Helen, O Império Português no Sul da América. Estancieiros, lavradores e comerciantes na constituição da estremadura portuguesa na América. Rio Grande de São Pedro, 1737-1822, Porto Alegre, Editora da Ufrgs, 2007.

Palacios, Guillermo y Fabio Moraga, La independencia y el comienzo de los regimenes representativos, Madrid, Síntesis, 2003, t. 1.

Palermo, Eduardo, “Los afro-fronterizos”, en Mallo y Telesca (coords.), 2010, pp. 190-191.

Palermo, Eduardo, "Secuestros y tráfico de esclavos en la frontera uruguaya: estudio de casos posteriores a 1850", en Revista Tema Livre, 13, s/d, http:// www.revistatemalivre.com/index.html; consultado el 23 de enero de 2012.

Peabody, Sue, "There Are no Slaves in France". The Political Culture of Race and Slavery in the Ancien Régime, Oxford, Oxford University Press, 1996.

Peabody, Sue y Keila Grinberg, Free Soil in the Atlantic World, Nueva York, Routledge, 2014.

Pesavento, Sandra, “Uma certa Revolução”, en Grinberg y Salles (coords.), 2009, 3 volúmenes.

Petiz, Silmei de Sant'Ana, Buscando a liberdade: as fugas de escravos da Provincia de São Pedro para o além-fronteira (1815-1851), Passo Fundo, Universidade de Passo Fundo, 2006. 
Reclamaciones de la República Oriental del Uruguay contra el Gobierno de Brasil, Montevideo, El País, 1864.

Resposta do conselheiro José Antonio Saraiva ao dr. Vasquez Sagastume, Bahia, Typographia e Encadernação do "Diário da Bahia”, 1894.

Saint Hilaire, Auguste de, Viagem ao Rio Grande do Sul, Brasilia, Senado Federal, 2002.

Salles, Ricardo, E o Vale era o escravo: Vassouras, século XIX. Senhores e escravos no coração do Império, Río de Janeiro, Civilização Brasileira, 2008.

SAlles, Ricardo, Guerra do Paraguai: escravidão e cidadania na formação do Exército, Río de Janeiro, Paz e Terra, 1990.

SCHNEIDER, Luiz, A Guerra da Tríplice Aliança contra o governo da República do Paraguai (1864-1870), con notas del Barón de Río Branco, Río de Janeiro, Typographia Americana, 1875-1876.

Secreto, María Verónica y Flávio dos Santos Gomes (coords.), Territórios ao Sul: Escravidão, escritas e fronteiras coloniais e pós-coloniais na América, Río de Janeiro, 7Letras, 2017.

SOAREs, Macedo, Campanha Jurídica pela Libertação dos Escravos (18671888), Río de Janeiro, Jose Olympio, 1938.

Sparks, Randy, Where the Negroes Are Masters: An African Port in the Era of the Slave Trade, Cambridge, Harvard University Press, 2014.

Torres, Miguel Gustavo de Paiva, O Visconde de Uruguai e sua atuação diplomática para a consolidação política externa do Império, Brasilia, Fundação Alexandre de Gusmão, 2011.

Villafañe Gomes Santos, Luís Cláudio, O Império e as Repúblicas do Pacífico: as relações do Brasil com Chile, Bolivia, Peru, Equador e Colômbia (1822-1889), Curitiba, Editora da UFPR, 2002.

Weber, Max, The City, Nueva York, Free Press, 1966. 